\title{
Benthic nitrogen fixation in the SW New Caledonia lagoon
}

\author{
Loïc Charpy ${ }^{1, *}$, Romain Alliod ${ }^{1}$, Martine Rodier $^{2}$, Stjepko Golubic ${ }^{3}$ \\ ${ }^{1}$ IRD, UR167 COM, Rue de la Batterie des Lions, 13007 Marseille, France \\ ${ }^{2}$ IRD, COM, Laboratoire d'Océanographie et de Biogéochimie, Faculté des Sciences de Luminy, Case 901, \\ 13288 Marseille Cedex 09, France \\ ${ }^{3}$ Department of Biology, Boston University, 5 Cummington Street, Boston, Massachusetts 02215, USA
}

\begin{abstract}
Various types of microbial mats are widespread in the SW New Caledonia lagoon. Both heterocystous (Nodularia harveyana) and non-heterocystous (Hydrocoleum cantharidosmum, $H$. lyngbyaceum) cyanobacteria dominate these mats. Using the acetylene reduction technique, nitrogenase activity was observed at all sites. Heterocystous cyanobacteria fix $\mathrm{N}_{2}$ during the daytime, whereas non-heterocystous cyanobacteria fix $\mathrm{N}_{2}$ during the night. The intensity of nitrogenase activity depended on the level of light energy received during daylight. An estimation of nitrogen fixation by benthic cyanobacteria $\left(16.4 \pm 5.4 \mathrm{mg} \mathrm{N}_{2} \mathrm{~m}^{-2} \mathrm{~d}^{-1}\right)$ at $21 \mathrm{~m}$ depth (average depth of the lagoon) represented $19 \%$ of the nitrogen requirement for benthic primary production.
\end{abstract}

KEY WORDS: Nodularia $\cdot$ Hydrocoleum $\cdot$ Microbial mats $\cdot$ Nitrogen fixation $\cdot$ Coral $\cdot$ Reef lagoon

\section{INTRODUCTION}

Biological nitrogen fixation is a process unique to prokaryotes, occurring commonly in freshwater and marine cyanobacteria. Although energetically demanding, this process provides them with a particular advantage when growing under the usual N-limited conditions of marine environments (Staal et al. 2001). Due to oxygen sensitivity of the nitrogenase enzyme, in an oxygen-producing organism, the fixation of carbon and nitrogen needs to be separated either in space or in time (Berman-Frank et al. 2003). Spatial separation is achieved in cyanobacteria that differentiate heterocysts as specialized nitrogen-fixing cells. It occurs also in some non-heterocystous cyanobacteria such as Trichodesmium (Bergman et al. 1997) and Katagnymene (Lundgren et al. 2001). These taxa fix nitrogen during the day, concurrent with photosynthetic activity, which energetically supports the process just as in heterocystous cyanobacteria. Other nonheterocystous cyanobacteria temporally separate nitrogen fixation and oxygenic photosynthesis: they fix nitrogen at night, using photosynthetic energy generated during the previous day (Lundgren et al. 2003).
Capone et al. (1997) considered that nitrogen fixation by Trichodesmium is likely a major input to the marine and global nitrogen cycle; this has recently been confirmed by Davis \& McGillicuddy (2006). Significant contribution is also expected from picoplanktonic cyanobacteria (Montoya et al. 2004). The search continues to include other contributors in plankton as well as benthos (Mahaffey et al. 2005).

Biological nitrogen fixation is a characteristic feature of many marine benthic phototrophically supported communities, with cyanobacteria considered the most important contributors (see Charpy-Roubaud et al. 2001). This activity also appears to make a major contribution to $\mathrm{N}$ supply in coral reef ecosystems, e.g. in Eniwetok Atoll, on the Great Barrier Reef, or in Tikehau Atoll lagoon, Tuamotu, French Polynesia (CharpyRoubaud et al. 2001). Many studies of nitrogen fixation have dealt with shallow areas of coral reefs (Larkum et al. 1988, D'Elia \& Wiebe 1990, Capone et al. 1992, Shashar et al. 1994) and exposed communities of an atoll rim (Charpy-Roubaud \& Larkum 2005). However, apart from our present study, very few investigations have focused on the soft substrata in lagoons (CharpyRoubaud et al. 2001). 
In the SW New Caledonia lagoon, a variety of microbial mats were found, including domes, shapeless gelatinous masses, and horizontally spreading mats of various shapes and sizes (Pringault et al. 2005). Photosynthetic production and community respiration were investigated for 1 yr in this lagoon (Clavier \& Garrigue 1999), but no data are available on the contribution of nitrogen fixation to these fluxes.

In the present study, we measured acetylene reduction rates in microbial mats of the SW New Caledonia lagoon. The objectives were to (1) identify dominant nitrogen fixers in benthic cyanobacterial communities, (2) measure their nitrogen fixation rates, (3) evaluate their importance compared to other benthic nitrogen fluxes and (4) test the dependence of nitrogen fixation rates on photosynthetic activity at different photon fluxes.

\section{MATERIALS AND METHODS}

Sites and sampling. The floor of the SW New Caledonia lagoon comprises $95 \%$ sediments. The average depth is $21 \mathrm{~m}$. We examined the 2 stations surveyed by Pringault et al. (2005) in this lagoon: Tabu Reef (TABU) and $\mathrm{M}^{\prime}$ Bo islet (MBO). In addition, we sampled 3 other islets - Banc Ouest (BAO), Lareignere (LAR) and Seche Croissant (SECR) - and a shallow station close to the IRD laboratory in Vata beach (VATA) and Stn M33, considered to be representative of the lagoon because of its depth $(21 \mathrm{~m})$, similar to the average depth of the SW New Caledonia lagoon. No stations were located inside the bays (Fig. 1). Details on sampling stations are presented in Table 1.

Cyanobacterial mats were carefully collected by SCUBA diving and then stored in seawater collected at the same place and depth. After sampling, mats were rapidly transferred to the laboratory for nitrogenase activity measurements.

Environmental parameters. At each station, conductivity and temperature depth profiles (CTD) were recorded. Water samples were taken from the water column above the sites where the benthic mats were sampled. Conductivity, temperature and turbidity profiles were acquired with a SeaBird SBE 19 profiler. Data processing was done with the Seabird Data Processing program.

Water samples for nutrients and chlorophyll were collected with Niskin bottles (5 l) along the water column down to less than $5 \mathrm{~m}$ above the bottom. Ammonium concentration was determined immediately with a Turner Design TD-700, using the fluorometric and $o$-phthaldialdehyde method described in Holmes et al. (1999). Nitrate $\left(\mathrm{NO}_{3}\right)$ and soluble reactive phosphate (SRP) were analyzed on $\mathrm{HgCl}_{2}$-preserved samples. Nitrate concentrations were determined by colorimetry using a Technicon ${ }^{\circledR}$ Autoanalyzer and standard techniques (Strickland \& Parsons 1972). SRP concentrations were measured with a $\mathrm{Cecil}^{\circledR} \mathrm{CE} 1011$ (10 cm cell length) spectrophotometer, using the molybdenum blue reaction (Murphy \& Riley 1962).

Chlorophyll a (chl a) was used as a proxy of phytoplankton biomass in the lagoon and measured in different size fractions: total, 3-10 and >10 $\mu \mathrm{m}$. Total chl a was determined on $100 \mathrm{ml}$ samples filtered onto Whatman GF/F. For the size-fractionated chl $a_{\text {, }}$ $1800 \mathrm{ml}$ were first pre-filtrated using 3 and $10 \mu \mathrm{m}$ Isopore (Millipore) membranes. Chl a was extracted in methanol on preserved samples and measured by fluorometry as described by Le Bouteiller et al. (1992).

Particulate $\mathrm{C}$ and $\mathrm{N}$ of benthic cyanobacteria were measured using an Integra-CN PDZ EUROPA mass spectrometer calibrated with glycine references. The accuracy of the analytical system was also regularly verified using reference materials from the International Atomic Energy Agency (IAEA, Analytical Quality Control Services).

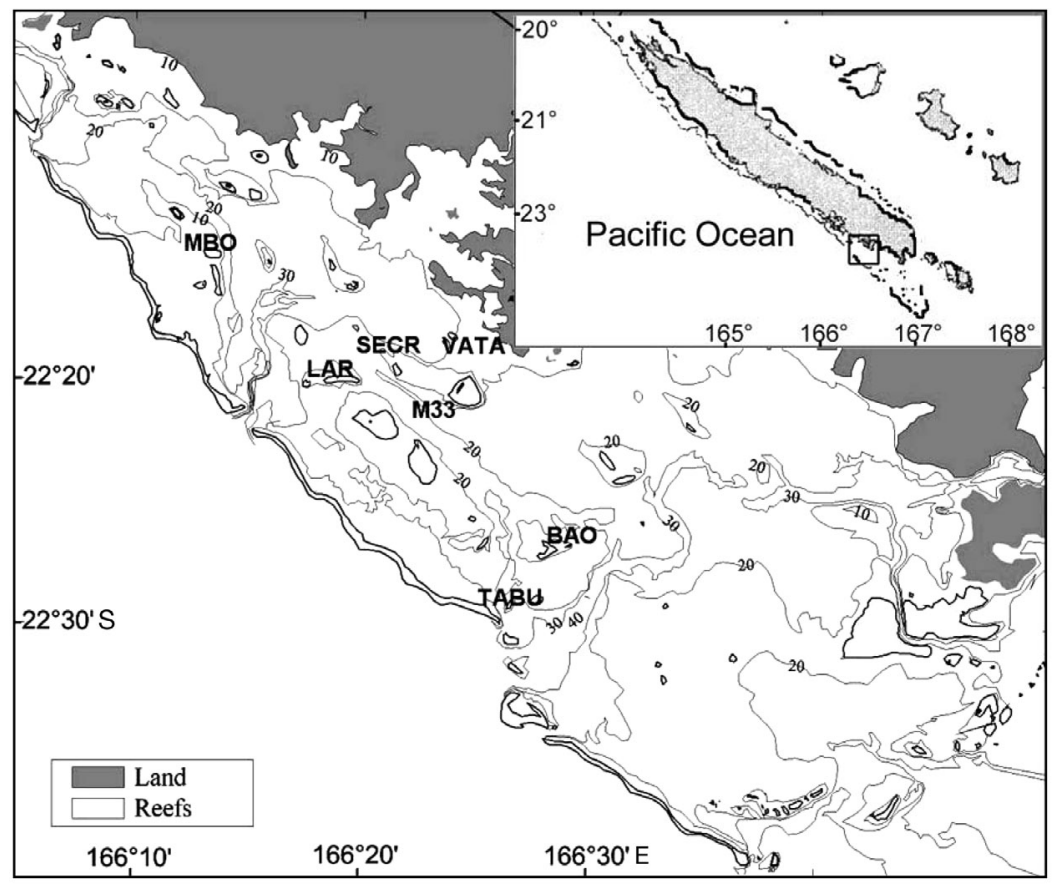

Fig. 1. Study area and the 7 stations surveyed in the SW New Caledonia lagoon. BAO: Banc Ouest; LAR: Lareignere; MBO: M'Bo islet; M33: Stn M33; SECR: Seche Croissant; TABU: Tabu Reef; VATA: Vata beach 
Table 1. Locations and descriptions of the stations surveyed (see Fig. 1 legend for full station names)

\begin{tabular}{|c|c|c|c|}
\hline Stn & Location & Depth (m) & Description \\
\hline TABU & $\begin{array}{l}22^{\circ} 28.876^{\prime} \mathrm{S} \\
166^{\circ} 26.746^{\prime} \mathrm{E}\end{array}$ & 5 & $\begin{array}{l}\text { Bank located close to the ocean, } \\
\text { white sand, many holothurians }\end{array}$ \\
\hline MBO & $\begin{array}{l}22^{\circ} 14.408^{\prime} \mathrm{S} \\
166^{\circ} 13.737^{\prime} \mathrm{E}\end{array}$ & 5 & $\begin{array}{l}\text { Islet located at the NW of the lagoon, } \\
\text { sand with Halodule uninervis, } \\
\text { Caulerpa racemosa, C. taxifolia, and } \\
\text { patch reefs of Acropora florida }\end{array}$ \\
\hline $\mathrm{BAO}$ & $\begin{array}{l}22^{\circ} 26.352^{\prime} \mathrm{S} \\
166^{\circ} 29.492^{\prime} \mathrm{E}\end{array}$ & 5 & $\begin{array}{l}\text { Islet located at the SE centre of the } \\
\text { lagoon, grey sand with patch reefs of } \\
\text { A. florida }\end{array}$ \\
\hline LAR & $\begin{array}{l}22^{\circ} 19.580^{\prime} \mathrm{S} \\
166^{\circ} 18.930^{\prime} \mathrm{E}\end{array}$ & $6-11$ & $\begin{array}{l}\text { Islet located close to the ocean, grey } \\
\text { sand with Halimeda cylindracea and } \\
\text { seagrass H. uninervis }\end{array}$ \\
\hline SECR & $\begin{array}{l}22^{\circ} 19.195^{\prime} \mathrm{S} \\
166^{\circ} 21.480^{\prime} \mathrm{E}\end{array}$ & 12 & $\begin{array}{l}\text { Islet located in the middle of the } \\
\text { lagoon, grey sand, with many } \\
\text { Opheodesoma australiensis }\end{array}$ \\
\hline VATA & $\begin{array}{l}22^{\circ} 18.669^{\prime} \mathrm{S} \\
166^{\circ} 26.715^{\prime} \mathrm{E}\end{array}$ & 1.2 & $\begin{array}{l}\text { Located close to the Anse Vata } \\
\text { beach, dark grey sand }\end{array}$ \\
\hline M33 & $\begin{array}{l}22^{\circ} 20.080^{\prime} \mathrm{S} \\
166^{\circ} 28.020^{\prime} \mathrm{E}\end{array}$ & 21 & $\begin{array}{l}\text { Centre of the lagoon, grey sand } \\
\text { without visible microbial mats }\end{array}$ \\
\hline
\end{tabular}

cy was expressed as ARR per chl a. The analytical method was the same as described above for phytoplankton (Le Bouteiller et al. 1992). Results are presented as gross nitrogen fixation calculated by using factor 4 in conversion from ARR (Mulholland et al. 2004).

\section{RESULTS}

\section{Environmental parameters}

The weather was rainy during the 2 wk experiment. Hydrological conditions in the SW New Caledonia lagoon were quite stable in space and time, with temperatures $(T)$ ranging from 23.8 to $25.0^{\circ} \mathrm{C}$ and salinity $(S)$ from 35.90 to $35.63 \mathrm{psu}$. The vertical TS and turbidity profiles were homogeneous throughout the water column, with a slight decrease in $T\left(<0.1^{\circ} \mathrm{C}\right)$ and $S$ $(<0.05 \mathrm{psu})$ near the bottom.

Nutrient concentrations showed no

Benthic nitrogenase activity measurements. Nitrogenase activity was estimated by measuring the acetylene reduction rate (ARR). Short- and long-term measurements were performed, using single injection of acetylene (Stewart et al. 1967). One $\mathrm{cm}^{2}$ of mat was placed inside $25 \mathrm{ml}$ glass bottles fitted with a septum and filled with $15 \mathrm{ml}$ of seawater from the sampling site. Experiments were started by the removal of $1 \mathrm{ml}$ air and the injection of the same volume of $\mathrm{C}_{2} \mathrm{H}_{2}$ followed by swirling for several minutes. Bottles (3 to 8 replicates) were incubated in a pool with continuous water circulation, covered with a nylon mesh absorbing $50 \%$ of the incident light. Twenty-seven bottles were covered with 1 layer and 9 bottles with 2 layers of the same nylon mesh, equivalent to 25 and $12.5 \%$ of the incident light, whereas 33 bottles were incubated in the dark. Light energy (PAR) was continuously recorded inside the pool using a miniature light recorder from Alec Electronics.

During and at the end of each incubation, after swirling for several minutes, a few $\mu$ l of gas mixture were used to measure $\mathrm{C}_{2} \mathrm{H}_{4}$ concentration using a gas chromatograph (Agilent $\mu \mathrm{GC}$ ) calibrated with commercial gas standards. Three replicates were carried out for each incubation bottle. ARR was calculated within each period by subtracting $\mathrm{C}_{2} \mathrm{H}_{4}$ formed in the preceding period.

The biomass of incubated benthic cyanobacteria was estimated from the chl a content. The relative efficien- coherent trend with depth, and the average values were representative of the whole water column down to the bottom. In the area studied, the average concentrations of nitrate and ammonium varied from 0.41 to 0.60 and 0.03 to $0.17 \mu \mathrm{M}$, respectively. Compared to dissolved inorganic nitrogen (DIN), the lagoon was low in SRP, with concentrations not exceeding $0.06 \mu \mathrm{M}$. The observed DIN:SRP ratios were therefore close to or greater than the Redfield ratio balance, indicating $\mathrm{N}$ sufficient conditions for growth. In the same area, the chl a concentration ranged from 0.11 to $0.37 \mu \mathrm{g} \mathrm{l}^{-1}$. The water column was dominated by the small size fraction phytoplankton $(<3 \mu \mathrm{m})$, which accounted for $83 \%$ of the total chl a biomass.

\section{Cyanobacteria in microbial mats}

Various types of organosedimentary structures occurred on the lagoon floor at the different sites surveyed (Table 1): green mats and tufts, dark-colored mats, globular orange-colored cyanobacterial colonies, cobweb-like soft gelatinous masses, and sand without evidence of cyanobacteria (Fig. 2). These structures differed in appearance, consistency, species composition and in their relationship to the substrate.

The green mats, covering large areas of the sandy bottom at Stn TABU at $5 \mathrm{~m}$ depth (Fig. 2A), were dominated by the heterocystous cyanobacterium Nodularia 

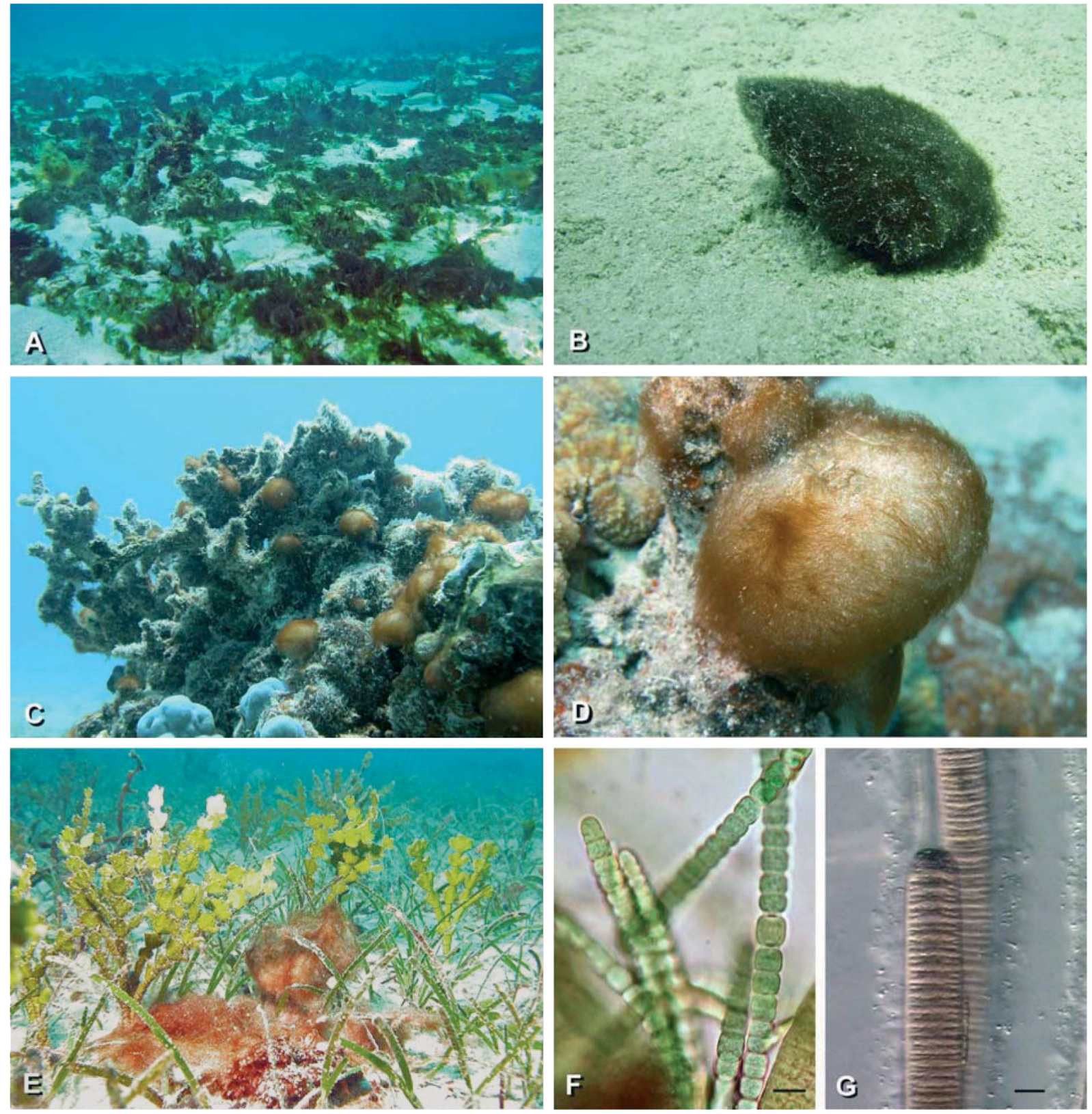

Fig. 2. Microbial mats of the SW New Caledonia lagoon. (A) Colonies of Nodularia harveyana widely distributed over the reef at Stn TABU at $5 \mathrm{~m}$ depth; (B) Hydrocoleum cantharidosmum colony on sand at Stn BAO (5 m); (C) young H. cantharidosmum mats on the reef at Stn MBO (5 m); (D) H. cantharidosmum colony in close-up view; (E) mats between seagrass Halodule uninervis and Halimeda cylindracea at Stn SECR $(12 \mathrm{~m}) ;(\mathrm{F}, \mathrm{G})$ photomicrographs of Nodularia harveyana and Hydrocoleum cantharidosmum, respectively (scale bars $=10 \mu \mathrm{m}$ ). Photos in (D) and (E) from E. Folcher; all other photos by L. Charpy

cf. harveyana. Other species were also present in these mats as minor constituents: Hydrocoleum lyngbyaceum, H. cantharidosmum, Oscillatoria cf. acuminata, Spirulina cf. tenerrima, Spirulina cf. subtilissima and Lyngbya confervoides.

Dark-colored mats (Fig. 2B), found mainly at Stns BAO and SECR, comprised a single species: Hydrocoleum cantharidosmum. The dark coloration was derived from a high concentration of phycoerythrin in their cells.

Orange gelatinous balls (Fig. 2C,D) attached to Acropora florida were made by Hydrocoleum cantharidosmum, together with $H$. lyngbyaceum, Lyngbya polychroa and $H$. holdeni as minor components. These mats were particularly abundant at Stns MBO and $\mathrm{BAO}$ at $5 \mathrm{~m}$ depth. The brown mats sampled at Stn 
VATA were dominated by $H$. lyngbyaceum, with Lyngbya cf. confervoides, H. cantharidosmum and Leptolyngbya sp. also present.

Cobweb-like mats covering Halimeda cylindracea and Halodule uninervis (Fig. 2E) at Stns SECR and LAR were dominated by Nodularia harveyana (Fig. 2F) and Hydrocoleum cantharidosmum (Fig. 2G). Hydrocoleum coccineum and Lyngbya cf. majuscula were also present in these mats.

The cyanobacterial assemblages inside sediments (Stn M33 at $21 \mathrm{~m}$ and Stn LAR at 6 and $11 \mathrm{~m}$ depth) were dominated by Symploca hydnoides and Nodularia harveyana. The species Lyngbya polychroa, Aulosira schauinslandii and Lyngbya confervoides were also present. The samples with absolute dominance by one organism were selected for experiments and measurement of ARR.

\section{Nitrogenase activity and light}

Incubation conditions, mean $\pm \mathrm{SE}$ of $\mathrm{C}_{2} \mathrm{H}_{4}$ concentrations, and ARR are presented in Table 2. Nitrogenase activity was observed in all communities, but it correlated differently with light conditions for different dominant species.

When incubated at $50 \%$ of incident light, the heterocystous Nodularia harveyana reduced $\mathrm{C}_{2} \mathrm{H}_{2}$ mainly

Table 2. Incubation conditions for acetylene reduction rate $(A R R$, mean $\pm S E)$ measurements. $t_{0}$ : time at start; $t_{\mathrm{f}}$ : time at end; $\mathrm{dt}$ : time of incubation; ILE: incident light energy; LE: light energy received during incubation; Chl a: cyanobacterial chlorophyll $a$

\begin{tabular}{|c|c|c|c|c|c|c|c|}
\hline $\begin{array}{l}t_{0} \\
(\mathrm{~h})\end{array}$ & $\begin{array}{c}t_{\mathrm{f}} \\
(\mathrm{h})\end{array}$ & $\begin{array}{l}\mathrm{dt} \\
(\mathrm{h})\end{array}$ & $\begin{array}{l}\text { ILE } \\
(\%)\end{array}$ & $\begin{array}{c}\mathrm{LE} \\
\left(\mu \mathrm{mol} \mathrm{m} \mathrm{m}^{-2} \mathrm{~s}^{-1}\right)\end{array}$ & $\begin{array}{l}\mathrm{C}_{2} \mathrm{H}_{4} \\
\text { (nmol) }\end{array}$ & $\begin{array}{l}\text { Chl a } \\
(\mu \mathrm{g})\end{array}$ & $\begin{array}{c}\mathrm{ARR} \\
\left(\mathrm{nmol} \mathrm{C} \mathrm{H}_{4} \mu \mathrm{g}^{-1} \mathrm{chl} \mathrm{a} \mathrm{h}^{-1}\right)\end{array}$ \\
\hline \multicolumn{8}{|c|}{ Nodularia harveyana } \\
\hline $15: 00$ & $18: 35$ & 3.6 & 50 & $427.4 \pm 22.7$ & $166.3 \pm 15.8$ & 1.61 & $28.8 \pm 2.7$ \\
\hline $18: 35$ & 06:00 & 11.4 & 50 & $3.0 \pm 0.6$ & $208.0 \pm 28.4$ & 1.61 & $2.3 \pm 0.7$ \\
\hline 06:00 & $14: 45$ & 8.8 & 50 & $1042 \pm 35.5$ & $326.0 \pm 18.9$ & 1.61 & $8.4 \pm 1.7$ \\
\hline $15: 15$ & $15: 57$ & 0.7 & 0 & $0.0 \pm 0.0$ & $10.0 \pm 2.1$ & 8.73 & $1.6 \pm 0.3$ \\
\hline $15: 57$ & $17: 26$ & 1.5 & 0 & $0.0 \pm 0.0$ & $20.2 \pm 4.0$ & 8.73 & $0.8 \pm 0.2$ \\
\hline $17: 26$ & 19:35 & 2.2 & 0 & $0.0 \pm 0.0$ & $31.1 \pm 7.0$ & 8.73 & $0.6 \pm 0.2$ \\
\hline 19:35 & 07:00 & 11.4 & 0 & $0.0 \pm 0.0$ & $49.2 \pm 11.0$ & 8.73 & $0.2 \pm 0.0$ \\
\hline 07:00 & 11:10 & 4.2 & 0 & $0.0 \pm 0.0$ & $51.0 \pm 11.0$ & 8.73 & $0.1 \pm 0.0$ \\
\hline \multicolumn{8}{|c|}{ Hydrocoleum cantharidosmum } \\
\hline $14: 20$ & $17: 20$ & 3.0 & 50 & $491.7 \pm 25.3$ & $0.0 \pm 0.0$ & 2.29 & $0.0 \pm 0.0$ \\
\hline $17: 20$ & 10:00 & 16.7 & 50 & $148.3 \pm 10.4$ & $229.9 \pm 37.1$ & 2.29 & $6.0 \pm 0.9$ \\
\hline $14: 20$ & $15: 20$ & 1.0 & 0 & $0.0 \pm 0.0$ & 0.0 & 3.30 & 0.0 \\
\hline $15: 20$ & $17: 00$ & 1.7 & 0 & $0.0 \pm 0.0$ & 0.0 & 3.30 & 0.0 \\
\hline $17: 00$ & $15: 20$ & 22.3 & 0 & $0.0 \pm 0.0$ & 59.3 & 3.30 & 0.8 \\
\hline $15: 00$ & $18: 47$ & 3.8 & 50 & $427.4 \pm 22.7$ & $0.0 \pm 0.0$ & 0.81 & $0.0 \pm 0.0$ \\
\hline $18: 47$ & 06:00 & 11.2 & 50 & $3.0 \pm 0.6$ & $68.5 \pm 10.8$ & 0.81 & $7.6 \pm 1.2$ \\
\hline 06:00 & $14: 55$ & 8.9 & 50 & $1042 \pm 35.5$ & $65.7 \pm 10.6$ & 0.81 & $0.0 \pm 0.0$ \\
\hline $15: 15$ & $16: 08$ & 0.9 & 0 & $0.0 \pm 0.0$ & $0.0 \pm 0.0$ & 2.54 & $0.0 \pm 0.0$ \\
\hline $16: 08$ & $17: 36$ & 1.5 & 0 & $0.0 \pm 0.0$ & $0.0 \pm 0.0$ & 2.54 & $0.0 \pm 0.0$ \\
\hline $17: 36$ & 07:00 & 13.4 & 0 & $0.0 \pm 0.0$ & $11.3 \pm 0.2$ & 2.54 & $0.3 \pm 0.0$ \\
\hline 07:00 & $11: 25$ & 4.4 & 0 & $0.0 \pm 0.0$ & $10.5 \pm 0.1$ & 2.54 & $0.0 \pm 0.0$ \\
\hline $16: 00$ & $11: 32$ & 19.5 & 25 & $100.3 \pm 5.7$ & $24.3 \pm 3.9$ & 6.1 & $0.2 \pm 0.0$ \\
\hline $16: 00$ & $11: 23$ & 19.4 & 25 & $100.3 \pm 5.7$ & $191.7 \pm 80.5$ & 9.86 & $1.0 \pm 0.4$ \\
\hline $16: 00$ & 09:55 & 17.9 & 25 & $103.6 \pm 5.9$ & $102.8 \pm 26.5$ & 4.05 & $1.4 \pm 0.4$ \\
\hline \multicolumn{8}{|c|}{ Hydrocoleum lyngbyaceum } \\
\hline $12: 00$ & $18: 19$ & 6.3 & 50 & $832.8 \pm 24.9$ & $0.9 \pm 0.9$ & 3.03 & $0.1 \pm 0.1$ \\
\hline $18: 19$ & $06: 15$ & 11.9 & 50 & $2.8 \pm 0.5$ & $320.3 \pm 71.5$ & 3.03 & $8.8 \pm 1.9$ \\
\hline $06: 15$ & 08:40 & 2.4 & 50 & $524.9 \pm 29.4$ & $320.7 \pm 64.4$ & 3.03 & $1.2 \pm 1.0$ \\
\hline $08: 40$ & $14: 20$ & 5.7 & 50 & $1320.0 \pm 9.0$ & $370.5 \pm 32.3$ & 3.03 & $0.0 \pm 0.0$ \\
\hline $12: 00$ & $18: 32$ & 6.5 & 25 & $411.9 \pm 12.5$ & $6.2 \pm 2.3$ & 3.93 & $0.2 \pm 0.1$ \\
\hline $18: 32$ & $06: 28$ & 11.9 & 25 & $1.4 \pm 0.3$ & $161.9 \pm 25.4$ & 3.93 & $3.3 \pm 0.5$ \\
\hline $06: 28$ & $08: 54$ & 2.4 & 25 & $262.5 \pm 14.7$ & $156.9 \pm 23.5$ & 3.93 & $0.0 \pm 0.0$ \\
\hline $12: 00$ & $18: 46$ & 6.8 & 12.5 & $206.0 \pm 6.2$ & $1.7 \pm 1.0$ & 4.05 & $0.1 \pm 0.0$ \\
\hline $18: 46$ & $06: 46$ & 12.0 & 12.5 & $0.7 \pm 0.1$ & $47.3 \pm 8.9$ & 4.05 & $0.9 \pm 0.2$ \\
\hline $06: 46$ & 09:12 & 2.4 & 12.5 & $131.2 \pm 7.4$ & $45.8 \pm 8.6$ & 4.05 & $0.0 \pm 0.0$ \\
\hline \multicolumn{8}{|l|}{ Sand } \\
\hline $16: 00$ & $11: 16$ & 19.3 & 25 & $100.3 \pm 5.7$ & $593.1 \pm 198.3$ & 22.90 & $1.3 \pm 0.4$ \\
\hline $16: 00$ & $09: 43$ & 17.7 & 25 & $103.6 \pm 5.9$ & $83.6 \pm 8.9$ & 1.20 & $3.9 \pm 0.4$ \\
\hline $16: 00$ & 09:53 & 17.9 & 25 & $103.6 \pm 5.9$ & $164.8 \pm 83.9$ & 3.23 & $2.9 \pm 1.4$ \\
\hline
\end{tabular}


during the daytime, with a maximum ARR value of $28.8 \pm 2.7 \mathrm{nmol} \mathrm{C}_{2} \mathrm{H}_{2}$ reduced $\mu^{-1} \mathrm{chl} \mathrm{a} \mathrm{h}^{-1}$ (Fig. 3). During the night, the ARR was lower but significant (2.3 \pm 0.7 nmol $\mathrm{C}_{2} \mathrm{H}_{2}$ reduced $\mu \mathrm{g}^{-1} \mathrm{chl} \mathrm{a} \mathrm{h}^{-1}$, Table 2). When incubated in the dark during the day, N. harveyana mats had a nitrogenase activity $(\mathrm{ARR}=1.6 \pm$ $0.3 \mathrm{nmol} \mathrm{C}_{2} \mathrm{H}_{2}$ reduced $\mu \mathrm{g}^{-1} \mathrm{chl} \mathrm{a} \mathrm{h}{ }^{-1}$, Table 2) 15 times lower than ARR under natural conditions.

In contrast to heterocystous cyanobacteria, the mats dominated by the non-hetrocystous cyanobacteria Hydrocoleum cantharidosmum and H. lyngbyaceum showed nitrogenase activity only during the night (Fig. 4). However, the level of ARR depended on the

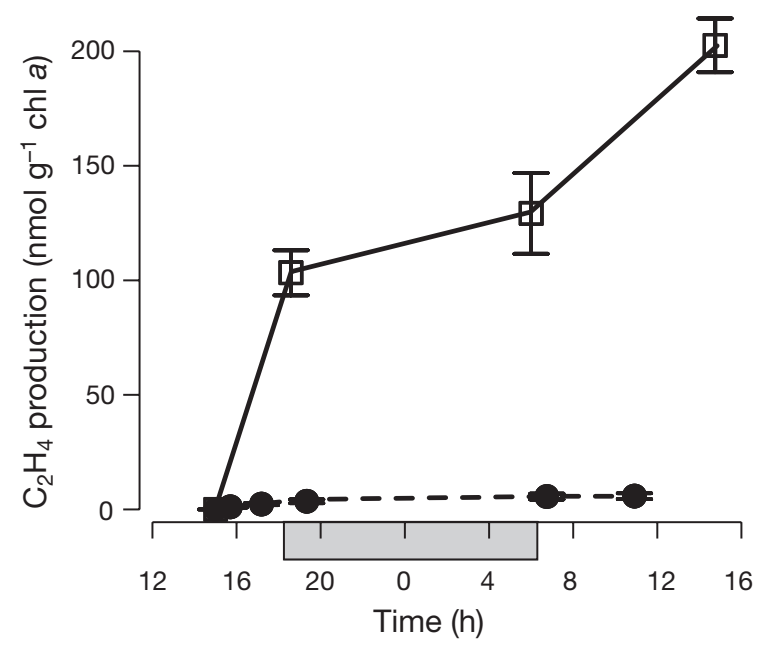

Fig. 3. Nodularia harveyana. $\mathrm{C}_{2} \mathrm{H}_{4}$ production per unit of chlorophyll by mats from Stn TABU (5 m depth) incubated under natural conditions ( $\square$ ) and in the dark during the day $(\bullet)$. Grey bar on the $x$-axis indicates nighttime

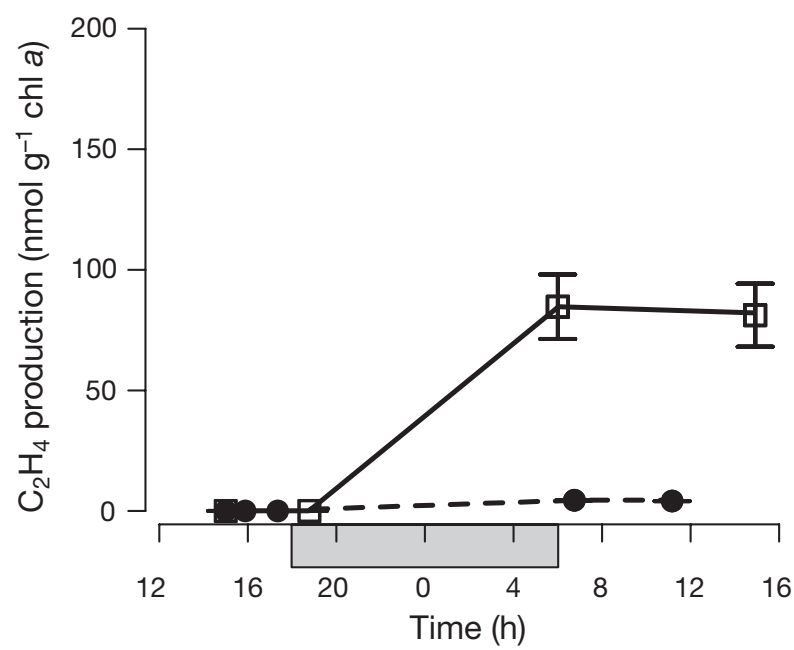

Fig. 4. Hydrocoleum cantharidosmum. $\mathrm{C}_{2} \mathrm{H}_{4}$ production per unit of chlorophyll by mats from Stn BAO (5 m depth) incubated under natural conditions ( $\square$ ) and in the dark during the day (๑). Grey bar on the $x$-axis indicates nighttime level of light energy received during the daytime. $H$. lyngbyaceum mats incubated during the daytime under 0 (in the dark, Fig. 4), 12.5, 25 and $50 \%$ of ambient light energy (Fig. 5) had night ARR values of 0, 0.9,

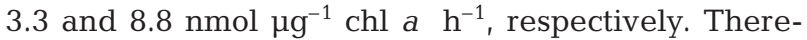
fore, nitrogenase activity depended on the light energy received during the previous day, indicating the high quantity of ATP produced via photosynthesis required for the nitrogen fixation process. The results show that ARR depth dependence is linked to the relationship between light, photosynthesis and ATP production. The 3 times higher nitrogenase efficiency of heterocystous (Nodularia harveyana; $28.5 \mathrm{nmol}$ ) vs. non-heterocystous cyanobacteria $(H$. cantharidosmum and $H$. lyngbyaceum; $8.8 \mathrm{nmol}$ ) can be explained by simultaneous production and utilization of ATP during the daytime by the former group.

\section{Daily nitrogenase activity}

The daily ARR was calculated using the $\mathrm{C}_{2} \mathrm{H}_{4}$ production over $24 \mathrm{~h}$ (Table 3). The highest values were observed for Nodularia harveyana mats collected at $5 \mathrm{~m}$ depth $\left(205 \pm 12 \mathrm{nmol} \mathrm{C}{ }_{2} \mathrm{H}_{2}{\mu \mathrm{gg}^{-1} \mathrm{chl} \mathrm{a} \mathrm{d}}^{-1}\right)$. Nitrogenase activity of the 2 species of Hydrocoleum mats was significantly lower; it was up to 5 times higher at shallow stations (82 to $123 \mathrm{nmol} \mathrm{C}_{2} \mathrm{H}_{2}{\mu \mathrm{gg}^{-1} \mathrm{chl} \mathrm{a} \mathrm{d}}^{-1}$ ) than at the deepest stations ( 24 to $34 \mathrm{nmol} \mathrm{C}_{2} \mathrm{H}_{2}{\mu \mathrm{g}^{-1} \mathrm{chl} \mathrm{a} \mathrm{d}}^{-1}$ ). The same trend was evident for cyanobacteria from sands, with ARR values decreasing linearly with depth.

Daily gross nitrogen fixation rates were calculated using a theoretical average value of 4 according to Mulholland et al. (2004), as discussed below. Nitrogen

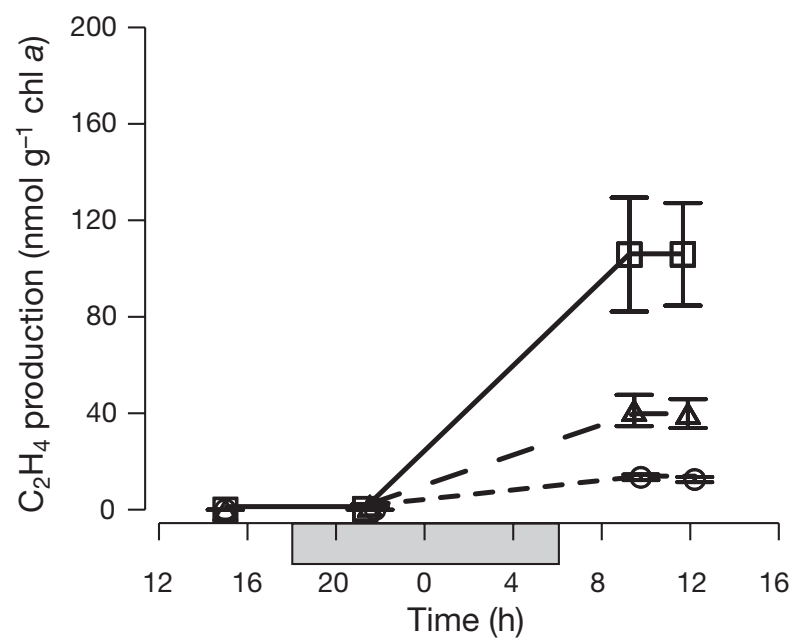

Fig. 5. Hydrocoleum lyngbyaceum. $\mathrm{C}_{2} \mathrm{H}_{4}$ production per unit of chlorophyll by mats from Stn VATA (1.2 m depth) incubated at $50 \%(\square), 25 \%(\Delta)$ and $12.5 \%(O)$ of incident light.

Grey bar on the $x$-axis indicates nighttime 
Table 3. Daily acetylene reduction rate (ARR) and nitrogen fixation rate (NF) of cyanobacteria mats incubated at different percentages of incident light energy (ILE)

\begin{tabular}{|c|c|c|c|c|c|}
\hline Mats (dominant cyanobacteria) & Stn & $\begin{array}{l}\text { Depth } \\
\text { (m) }\end{array}$ & $\begin{array}{l}\text { ILE } \\
(\%)\end{array}$ & $\begin{array}{c}\text { ARR } \\
\left(\mathrm{nmol} \mathrm{C} \mathrm{H}_{2} \mu \mathrm{g}^{-1} \mathrm{chl} a \mathrm{~d}^{-1}\right)\end{array}$ & $\begin{array}{c}\mathrm{NF} \\
\left(\mathrm{nmol} \mathrm{N} \mu_{2} \mathrm{gg}^{-1} \mathrm{chl} a \mathrm{~d}^{-1}\right)\end{array}$ \\
\hline Nodularia harveyana & TABU & 5 & 50 & $204.7 \pm 11.9$ & $51.2 \pm 3.0$ \\
\hline Hydrocoleum lyngbyaceum & VATA & 1.2 & 50 & $123.0 \pm 24.7$ & $30.8 \pm 6.2$ \\
\hline Hydrocoleum cantharidosmum & $\begin{array}{c}\text { MBO } \\
\text { BAO } \\
\text { SECR } \\
\text { LAR }\end{array}$ & $\begin{array}{c}5 \\
5 \\
12 \\
11\end{array}$ & $\begin{array}{l}50 \\
50 \\
25 \\
25\end{array}$ & $\begin{aligned} 122.3 & \pm 19.7 \\
81.5 & \pm 13.1 \\
24.1 & \pm 10.1 \\
34.0 & \pm 8.8\end{aligned}$ & $\begin{array}{r}30.6 \pm 4.9 \\
20.4 \pm 3.3 \\
6.0 \pm 2.5 \\
8.5 \pm 2.2\end{array}$ \\
\hline Sand & $\begin{array}{l}\text { LAR } \\
\text { LAR } \\
\text { M33 }\end{array}$ & $\begin{array}{c}6 \\
11 \\
21\end{array}$ & $\begin{array}{c}50 \\
25 \\
12.5\end{array}$ & $\begin{array}{l}94.3 \pm 10.0 \\
68.5 \pm 34.9 \\
32.3 \pm 10.8\end{array}$ & $\begin{array}{r}23.6 \pm 2.5 \\
17.1 \pm 8.7 \\
8.1 \pm 2.7\end{array}$ \\
\hline
\end{tabular}

fixation rates by mats varied between 6 (Hydrocoleum cantharidosmum mat at $12 \mathrm{~m}$ depth) and $51 \mathrm{nmol} \mathrm{N}_{2}$ $\mu^{-1}$ chl a d $\mathrm{d}^{-1}$ (Nodularia harveyana at $5 \mathrm{~m}$ depth). Sand nitrogen fixation varied from 8 (21 $\mathrm{m}$ depth) to

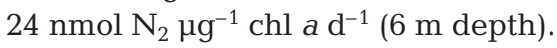

\section{DISCUSSION}

\section{Benthic cyanobacteria in coral reef ecosystems}

Microbial mats are associations of organisms dominated by cyanobacteria, although they often form complex microbial systems in association with nonoxygenic phototrophic, chemolithotrophic and organotrophic bacteria, and eukaryotic microorganisms (Golubic et al. 1999). When overgrowing the loose sandy and muddy seafloor, they tend to stabilize the sediment (Noffke et al. 2001) and often incorporate substantial quantities of fine grain carbonate (Charpy-Roubaud et al. 1999). They are also present in soft muddy floors of lagoons in New Caledonia (Pringault et al. 2005).

In coral reef ecosystems, benthic cyanobacteria are present as microbialites, i.e. organosedimentary deposits that combine microbial growth with mineral precipitation and/or trapping and binding of detrital sediment. Other cyanobacteria in benthic microbial formations include biofilms on hard substrates, microbial mats and epiphytes on macroalgae and benthic seagrass, and as symbionts in marine sponges and corals (reviewed by Charpy 2006).

In the sites surveyed in the present study, Nodularia and Hydrocoleum are the dominant genera of the mats. Hydrocoleum cantharidosmum was the only cyanobacterial species seen in black mats. Species of Hydrocoleum were reported to be very abundant in Tikehau Atoll lagoon (Abed et al. 2003), and Kabira reef sediments, Ishigaki Island, SW Japan (Kayanne et al. 2005). They are considered to be among the most common mat-forming cyanobacteria in tropical oceans with the genetic potential to fix nitrogen (Abed et al. 2006).

Mats collected in the SW New Caledonia lagoon represent a variety of morphotypes. As observed in Tikehau Atoll lagoon (Abed et al. 2003), these mats seem to be initially dominated by a single cyanobacterial taxon, but older mats contain a mixture of different morphotypes once the growth rate of the dominant organism slows down.

The taxonomy of cyanobacteria is currently in the process of re-evaluation by application of the combined molecular sequencing and morphological analyses known as the polyphasic approach (Abed et al. 2003). Among the planktonic nitrogen-fixing cyanobacteria, a taxonomic revision has been recently introduced by unifying the genera Trichodesmium and Katagnymene (Lundgren et al. 2005). The relationship among cyanobacterial genera and species has yet to be resolved in terms of phylogenetic and morphotypic distinctions. However, a number of morphotypic characterizations and species determinations of museum specimens performed over $100 \mathrm{yr}$ ago withstood the scrutiny of molecular evaluation and were confirmed (Palinska et al. 2006). The genetic potential to fix nitrogen by Hydrocoleum, the most common benthic cyanobacterium genus in the SW New Caledonia lagoon has been documented for the same area by identifying the nifH gene sequences and established close phylogenetic relationship to the Trichodesmium cluster, indicating common origins of the main planktonic and benthic nitrogen-fixing cyanobacteria (Abed et al. 2006).

\section{Nitrogen fixation}

The acetylene reduction method does not measure nitrogen fixation rates directly; it needs to be cali- 
brated by calculating the $\mathrm{C}_{2} \mathrm{H}_{2}: \mathrm{N}_{2}$ ratio (mol:mol). Multiple studies have shown the conversion ratio of ethylene to $\mathrm{N}$ to be highly variable. In coral reef ecosystems, values for benthic mats range from 1.8 to 4.8 in Tuamotu Atoll lagoon (CharpyRoubaud et al. 2001) and from 0.3 to 4.7 in Kabira reef (Kayanne et al. 2005). At least 2 factors contribute to the deviation from the theoretical ratio: the release of recently fixed nitrogen as inorganic or organic $\mathrm{N}$, and the release of nitrogenasedependent $\mathrm{H}_{2}$, which is inhibited by $\mathrm{C}_{2} \mathrm{H}_{2}$ (Mulholland et al. 2004). These authors concluded that ${ }^{15} \mathrm{~N}_{2}$ uptake approximates net $\mathrm{N}$-specific growth rates while the $\mathrm{C}_{2} \mathrm{H}_{2}$ reduction technique provides a good estimate of gross nitrogen fixation. When considering total ${ }^{15} \mathrm{~N}_{2}$ fixation (sum of PON plus released DON and $\mathrm{NH}_{4}{ }^{+}$), a conversion ratio of $4: 1$ is appropriate for quantification of gross nitrogen fixation as measured by $\mathrm{C}_{2} \mathrm{H}_{2}$ reduction

High nitrogen fixation rate per unit of chlorophyll by Nodularia harveyana compared to the rate by non-heterocystous cyanobacteria is apparently due to the fact that nitrogenase is directly supplied with energy and low-potential electrons during the time of active photosynthesis (see Stal 1999).

Data on nitrogen fixation for coral reef mats are relatively rare and are mainly expressed per square meter of substrate rather than per unit of chl a. Our results can be directly compared only to the data set of Kayanne et al. (2005). Accordingly, nitrogen fixation rates of Hydrocoleum cantharidosmum and $H$. lyngbyaceum mats of the SW New Caledonia lagoon were 8 to 12 times higher than the value given for the same species in the coral reef ecosystem of Kabira reef.

Data sets of nitrogen fixation by soft substrates are more numerous and can be compared to our results expressed by square meter of substrata by using the area of incubated sediment $\left(3.14 \mathrm{~cm}^{2}\right)$. The floor of the SW New Caledonia lagoon is made of $95 \%$ sediments and the average depth is $21 \mathrm{~m}$. Therefore, we consider that nitrogen fixation rates measured in sediments from Stn M33 are representative of the lagoon. The nitrogen fixation rate at Stn M33 at 21 m depth was on average $586 \pm 193 \mu \mathrm{mol} \mathrm{N} \mathrm{m}^{-2} \mathrm{~d}^{-1}$. This value is very high compared with other data on sediment fixation rates (Table 4), but 2 times lower than the nitrogen fixation rate given by Shashar et al. (1994) for Eilat (Red Sea) sand.

\section{Nitrogen fixation as an input to sediment primary production}

To estimate the contribution of nitrogen fixation to the total nitrogen requirement for benthic primary production, we assumed that nitrogen fixation at the sediment water interface is also $\mathrm{N}$ supply to local microphytobenthic production. The average microphytobenthic primary production of New Caledonia sands was estimated to be $47.7 \mathrm{mmol} \mathrm{C} \mathrm{m}^{-2} \mathrm{~d}^{-1}$ (Clavier \& Garrigue 1999). The average C:N ratio of our benthic cyanobacteria was $6.74 \pm 1.21(\mathrm{w}: \mathrm{w})$. Based on these values, the nitrogen requirement for microphytobenthic primary production was $84.9 \mathrm{mg} \mathrm{N} \mathrm{m}^{-2} \mathrm{~d}^{-1}$. Therefore, nitrogen fixation (16.4 $\mathrm{mg} \mathrm{N}_{2} \mathrm{~m}^{-2} \mathrm{~d}^{-1}$ ) represents $19 \%$ of that required for benthic primary production, which is nearly 10 times higher than the percentage ( $2 \%$ ) given by Charpy-Roubaud et al. (2001) for Tikehau Atoll lagoon.

\section{SUMMARY}

Microbial mats, dominated and structured by benthic cyanobacteria, are widespread on the floor of the tropical SW New Caledonia lagoon. Both heterocystous and non-heterocystous cyanobacteria were identified in these mats and analyzed using acetylene reduction assay. The results show that their nitrogen fixation rates are significant contributors to the nitrogen budget in the benthos. The heterocystous Nodularia harveyana mats that fixed nitrogen mainly during the daytime were 3 times more efficient (per unit of chlorophyll) than non-heterocystous cyanobacteria that fixed nitrogen during the night. Nitrogen fixation by non- 
heterocystous species of Hydrocoleum depends on the energy supplied by photosynthesis the previous day. Their nitrogen-fixing efficiency correlates positively with the light intensity to which they were exposed. Nitrogen fixation by benthic cyanobacteria contributes up to $19 \%$ of the total requirement of benthic primary production.

Acknowledgements. This work was supported by a grant of the 'Programme National Environnement Côtier' (PNEC). International collaboration was supported by the Alexander von Humboldt Foundation, Bad Godesberg, Germany, and Hanse Institute for Advanced Studies, Delmenhorst, Germany. We thank the sailors of the Noumea IRD boats and the diver E. Folcher for his help during sampling and for the photos in Fig. 2D,E. We also thank Valerie Sandroni for determining the mat $\mathrm{C}: \mathrm{N}$ ratio.

\section{LITERATURE CITED}

Abed RMM, Golubic S, Garcia Pichel F, Camoin GF, Sprachta S (2003) Characterization of microbialite-forming cyanobacteria in a tropical lagoon: Tikehau Atoll, Tuamotu, French Polynesia. J Phycol 39:862-873

Abed RMM, Palinska KA, Camoin G, Golubic S (2006) Common evolutionary origin of planktonic and benthic nitrogen-fixing oscillatoriacean cyanobacteria from tropical oceans. FEMS Microbiol Lett 260:171-177

Bergman B, Gallon JR, Rai AN, Stal LJ (1997) Nitrogen fixation by non-heterocystous cyanobacteria. FEMS Microbiol Rev 19:139-185

Berman-Frank I, Lundgren P, Falkowski P (2003) Nitrogen fixation and photosynthetic oxygen evolution in cyanobacteria. Res Microbiology 154:157-165

Capone DG, Dunham SE, Horrigan SG, Duguay LE (1992) Microbial nitrogen transformations in unconsolidated coral reef sediments. Mar Ecol Prog Ser 80:75-88

Capone DG, Zehr JP, Paerl HW, Bergman B, Carpenter EJ (1997) Trichodesmium, a globally significant marine cyanobacterium. Science (Wash DC) 276:1221-1229

Charpy L (2006) Importance of cyanobacteria in coral reef ecosystems. In: Suzuki Y (ed) 10th Int Coral Reef Symp, Okinawa (Japan), p 775-784

Charpy-Roubaud C, Larkum A (2005) Dinitrogen fixation by exposed communities on the rim of Tikehau atoll (Tuamotu Archipelago, French Polynesia). Coral Reefs 24:622-628

Charpy-Roubaud C, Le Campion T, Golubic S, Sarazin G (1999) Recent cyanobacterial stromatolites in the lagoon of Tikehau Atoll (Tuamotu Archipelago, French Polynesia): preliminary observations. In: Charpy L, Larkum AWD (eds) Marine cyanobacteria. Bull Inst Oceanogr Monaco 19:121-125

Charpy-Roubaud C, Charpy L, Larkum AWD (2001) Atmospheric dinitrogen fixation by benthic communities of Tikehau Lagoon (Tuamotu Archipelago, French Polynesia) and its contribution to benthic primary production. Mar Biol 139:991-997

Clavier J, Garrigue C (1999) Annual sediment primary production and respiration in a large coral reef lagoon (SW New Caledonia). Mar Ecol Prog Ser 191:79-89

Davis CS, McGillicuddy DJ Jr (2006) Transatlantic abundance of the $\mathrm{N}_{2}$-fixing colonial cyanobacterium Trichodesmium. Science 312:1517-1520

D'Elia CF, Wiebe WJ (1990) Biogeochemical nutrient cycles in coral-reef ecosystems. In: Dubinski Z (ed) Coral reefs. Elsevier Science Publishers, Amsterdam, p 49-74

Golubic S, Le Campion-Alsumard T, Campbell SE (1999)
Diversity of marine cyanobacteria. In: Charpy L, Larkum AWD (eds) Marine cyanobacteria. Bull Inst Oceanogr Monaco 19:53-76

Holmes RM, Aminot A, Kérouel R, Hooker BA, Petersen BJ (1999) A simple and precise method for measuring ammonium in marine and freshwater ecosystems. Can J Fish Aquat Sci 56:1801-1808

Kayanne H, Hirota M, Yamamuro M, Koike I (2005) Nitrogen fixation of filamentous cyanobacteria in a coral reef measured using three different methods. Coral Reefs 24: $197-200$

Larkum AWD, Kennedy IR, Muller WJ (1988) Nitrogen fixation on a coral reef. Mar Biol 98:143-155

Le Bouteiller A, Blanchot J, Rodier M (1992) Size distribution patterns of phytoplankton in the western Pacific: towards a generalization for the tropical open ocean. Deep-Sea Res 39:805-823

Lundgren P, Söderbäck E, Singer A, Carpenter EJ, Bergman B (2001) Katagnymene: characterization of a novel marine diazotroph. J Phycol 37:1052-1062

Lundgren P, Bauer K, Lugomela C, Söderbäck E, Bergman B (2003) Reevaluation of the nitrogen fixation behavior in the marine non-heterocystous cyanobacterium Lyngbya majuscula. J Phycol 39:310-314

Lundgren P, Janson S, Jonasson S, Singer A, Bergman B (2005) Unveiling of novel radiations within Trichodesmium cluster by hetR gene sequence analysis. Appl Environ Microbiol 71:190-196

Mahaffey C, Michaels AF, Capone DG (2005) The conundrum of marine $\mathrm{N}_{2}$ fixation. Am J Sci 305:546-595

Montoya JP, Holl CM, Zehr JP, Hansen A, Villreal TA, Capone DG (2004) High rates of $\mathrm{N}_{2}$-fixation by unicellular diazotrophs in the oligotrophic Pacific Ocean. Nature 430: 1027-1031

Mulholland MR, Bronk DA, Capone DG (2004) Dinitrogen fixation and release of ammonium and dissolved organic nitrogen by Trichodesmium IMS101. Aquat Microb Ecol 37:85-94

Murphy J, Riley JP (1962) A modified single solution method for the determination of phosphate in natural waters. Anal Chim Acta 26:31-36

Noffke N, Gerdes G, Klenke T, Krumbein WE (2001) Microbially induced sedimentary structures-a new category within the classification of primary sedimentary structures. J Sediment Res 71:649-656

Palinska KA, Thomasium CF, Marquardt J, Golubic S (2006) Phylogenetic evaluation of cyanobacteria preserved as historic herbarium exsiccata. Int J Syst Evol Microbiol 56:(doi 10.1099/ijs.0.64417-0)

Pringault O, de Wit R, Camoin G (2005) Irradiance regulation of photosynthesis and respiration in modern marine microbialites built by benthic cyanobacteria in a tropical lagoon (New Caledonia). Microb Ecol 49:604

Shashar N, Feldstein T, Cohen Y, Loya Y (1994) Nitrogen fixation (acetylene reduction) on a coral reef. Coral Reefs 13: 171-174

Staal M, Meysman FJR, Stal LJ (2001) Temperature excludes $\mathrm{N}_{2}$-fixing heterocystous cyanobacteria in the tropical oceans. Nature 425:505-507

Stal LJ (1999) Nitrogen fixation in microbial mats and stromatolites. In: Charpy L, Larkum AWD (eds) Marine cyanobacteria. Bull Inst Océanogr Monaco (numéro spécial) 19:357-363

Stewart WDP, Fitzgerald GP, Burris RH (1967) In situ studies on $\mathrm{N}_{2}$ fixation using the acetylene reduction technique. Biochemistry 58:2071-2078

Strickland JDH, Parsons TR (1972) A practical handbook of seawater analysis, 2nd edn. J Fish Res Board Can 167:311 